\title{
PERSONAL CAREER ANCHORS OF THE UNIVERSITY STUDENTS
}

\author{
[Osobní kariérové kotvy studentů vysokých škol]
}

\author{
Dagmar Svobodová ${ }^{1}$ \\ ${ }^{1}$ Silesian University, School of Business Administration, Univerzitní nám. 1934/3, 73340 Karviná \\ Email:svobodova@opf.slu.cz
}

\begin{abstract}
An intention is to identify the impact and effects of distribution of personal career anchors of university students during clarifying of career expectations and formation of professional selfconception. The aim is to compare the distribution of personal career anchors according to the type of study program and the form of university study. The first chapter describes the types of personal career anchors in interpretation of Schein's concept. The second chapter presents the methodology of questionnaire survey concerning the personal career anchors. The third chapter interprets and discusses the results of the cluster analysis of the questionnaire survey concerning the distribution of personal career anchors of four subsets of students of SU OPF in the academic year 2014/2015. The conclusion confirms the usefulness of the cognition of Schein's concept of personal career anchors for clarification of career expectations and formation of professional self-conception of the university students of SU OPF Karviná.
\end{abstract}

Keywords: career anchor, motivation, Schein's concept, university student.

JEL classification: J2, J24

Doručeno redakci: 8.2.2016; Recenzováno: 16.2.2015; 28.3.2015; Schváleno k publikování: 26.5.2016

\section{Introduction}

The aim of the essay is to recognize the career anchors of university students according to Schein's concept and compare their distribution by the type of study program and the form of university study taking into consideration two viewpoints. ${ }^{1}$ At first, whether and how the distribution of personal career anchors may assist the university students in clarifying of career expectations, and at second, whether and how the different types of career anchors may form the professional self-conception of university students. How will university students realize the effects of Schein's concept of personal career anchors for clarifying the career expectations and formation of professional self-conception? How will they find out where they have the strongest personal career anchor? Do the university students from selective subsets think that the personal career anchors of Schein's concept fit them all equally? What is the similarity and difference in preferences of personal career anchors of university students in selection subsets according to the type of study program and forms of the university study? From the viewpoint of Schein's concept of career anchors, a clarification of career expectations and formation of professional self-conception according to the motivation of university students to the working activity can be expected. The university students need for a professional career in the labour market mainly to meet the needs of self-realization. By realizing the Schein's concept of personal career anchors then they will effectively clarify the career expectations and form the professional selfconception. The listed attributes will contribute to their deciding, what type of career they shall choose in the future.

\footnotetext{
${ }^{1}$ SU OPF, 2015. Study in Karviná. Information concerning the study for the academy year 2015/2016 [online] [vid. $5^{\text {th }}$ November 2015]. Available from: studujvkarvine.cz/opf.slu.cz/
} 


\section{Concept of career anchors}

The concept of career anchors was developed, based on his own research, by the American Schein. Schein's research concerned a long-term monitoring of of graduates' professional careers of the Sloan School from Management Institute of Technology in Massachusetts (Schein, 1990). The career anchors are developed in early years of the occupation by the process, when an individual acquires the work and life experiences and learns to know oneself. When the occupational self-conception is formed, it acts as a stabilizing force and remains unchanged. It contains values and motives, which the individual does not give up when he is forced to make important decisions in the professional career. The career anchor influences a choice of the professional career and a decision whether to change a job, including a viewpoint of an individual on the professional future. The career anchor acts as a restraining force not only during choosing the career and the employment, but also during choosing a working environment. The term of career anchor is apt, because it affects the individual's choice of job and a choice of professional career. Releasing the career anchors requires an effort and, as Schein (1978) mentions, it cannot be expected that a dramatic change in career anchoring of the individual occurs routinely (Lemrová, Vtípil, 2005).

Based on results of the research concerning the monitoring of professional careers of graduates, Schein (1994) defines the term "career anchor" as a model of three components. The first component of a career anchor is the image of personal talent and abilities which is based on the current success of an individual in various work situations (Bělohlávek, 1994). The second component is the personal image of motives and needs which is based on selfrealization of an individual in real situations and on feedback of the social environment. The self-image of motives and needs can be characterized as "motivational anchor", which describes as a structure of the motivational field. The motivational field according consists of motivational orientation, motivational position and motivational tuning. The motivational orientation is related to the personal qualities of an individual, which do not change during the career. It forms the basis of motivation field and a framework for further motivation components. In human behaviour, the motivational orientation dominates, if the individual comes into an individual stress situation, requiring behaviour that he/she has not yet managed to learn. The motivational position is related to the permanently valid conditions of the professional career. It is a learned component which an individual adopts in response to the standard working conditions and it is associated with attention of an individual during clarifying of career expectations and formation of professional self-conception. The motivational tuning is likened to the "motivational weather", a variable depending on conditions of the professional career. It is an immediate response of the individual to impacting impulses. While the motivational orientation and motivational position of an individual is to be taken seriously, the motivational tuning contains a cure for itself that is contained in human nature. The motivational tuning is transient and the course of a professional career, which is associated with the changes, repeals it and changes therefore the current states of an individual in the labour market. The third component of the career anchor is the self-image of attitudes and values, which is based on the relationship between oneself on one side and the norms and values of the employer on the other. Career anchors in the interpretation of Schein (1996) can be understood as a subjective perception of one's own talent, motivation and values that are used by an individual for forming, stabilizing and integration of the personal career. The career anchor therefore influences a choice of career and a potential change of occupation, thus making and choice of the professional career (Evans, 1996). 


\subsection{Types of personal career anchors}

The dominant personal career anchor according to Schein (1996) in professional careers of individuals prevails. If the exercised profession is not in accordance with the dominant personal career anchor, the feelings of dissatisfaction with career are occurring (Feldman, Bolino, 1996). A compliance with the dominant personal career anchor is in contrarily positively reflected in higher professional performance, loyalty to an actual employment and satisfaction of an individual with the performed working activity. Salary, employer's benefits and promotion system are reflected into opportunities for career advancement. However, the studies indicate (Hardin, Stocks and Graves, 2001; Lee and Wong, 2004) that in a single profession are fulfilled the needs of an individual, which are bundled with other types of personal career anchors:

A - Anchor of material reward is regarded as a major stimulant in the professional career, because it is a source of existential resources, important for the life of an individual and his/her family. It may have not only the financial form (wages, salary, bonuses, target bonuses, bonuses related to higher performance), but also other forms that are less universal, bear more personal characteristics and are more effectively motivating the individual. For all kinds of rewards, however, there is a valid rule that an individual must be clear about the relationship between his/her effort and the reward.

B - Anchor of power/influence in terms of interpersonal competence such as the ability to influence, manage and lead the working group, and the emotional competence in bearing responsibilities and workload. Crisis situations are perceived as challenges and are stimulating through connection with personal responsibility for results of the organization.

C - Anchor of significance/meaning manifests itself by primary focus on the content of performed work, where it is necessary to organize the work in accordance with personal values, including the pursuit of reaching the beneficial issues not only for oneself but also for others a verb is missing. Including in the work not only the qualification and talent, but also other important values. The career decisions express wishes of ,,improvements of the working world". In case of a lack of support from both superiors and colleagues, there is a possibility to switch into a more independent professional career, into "free professions".

D - Anchor of expertness in terms of technical and functional competence is linked to a content of the work and expertness of the performed working activity with exceeding the vertical professional career. For an individual, an expert function and a preference of functional competence in his/her own field is acceptable, including analytical competence as an ability to work with information. The new working position must contain conditions for professional development. The improvement of professional skills is for an individual more important than money, even though he/she considers rewarding his/her professional knowhow as important.

$\mathbf{E}$ - Anchor of creativity signals a need to perform an activity, where a product of one's own creation is the result. This may be a new project, a business plan, a system or a company. After finishing of the product, however, the initial enthusiasm diminishes and the individual seeks a change that will be associated with creativity. Creative individuals dislike routine work activities and their management positioning in an organization is often problematic.

$\mathbf{F}$ - Anchor of sense of belonging is a solidarity and willingness of individuals to engage in achieving group goals based on mutual cooperation, including readiness to carry out what is expected of them. The individuals stick together, cooperate with each other and participate in an effort when they are showing interest in both working and interpersonal levels. In the workgroup or team, there exists the awareness "WE - GROUP", which separates the relevant human groups from the neighbourhood. A membership in it is manifested as a commitment of 
long-term orientation of the individual to the group's objectives and his/her interest to remain within the group.

$\mathbf{G}$ - Anchor of autonomy in terms of independence precludes individuals to accept rules that are necessary for work in employers' organizations. Autonomous individuals want to be individual, independent and free from organizational pressures. Usually they go through a separate business career in a "free profession ".

$\mathbf{H}$ - Anchor of security is a need of an individual to have a stable job, an income and benefits, leading to an effort to do what the employer wants. The security-oriented individual likes a work according to the rules and regulations of the employer, not according to performance of profession with a risk of independent decision-making.

I - Anchor of position has a meaning of a working position as a particular status in the organization, including managerial competence combined with motivation to achieve leader's working position. The status manifests itself in situations when a boss deals with a subordinate and where there their communication unidirectional may be.

\section{Research methodology and data specification}

The aim to compare the distribution of personal career anchors according to the type of study program and forms of university study, for a research method was selected. According to Reichel (2009, p. 99) the base of questioning is laying down questions, either in a speaking or written form (questionnaire). The questionnaire of personal career anchors became as a research technique for obtaining empirical data for respondents. The respondents had in the questionnaire 36 pairs of motivational statements, which they are clarifying the career expectations and are forming the professional self-conception. For an inclusion in the type of personal career anchors and evaluation, the individual motivational sayings were in the questionnaire coded by letters A, B, C, D, E, F, G, H, I. The respondents were asked to evaluate the importance of motivational sayings for themselves in each pair by division of points between 3 . The distribution of points according to an importance among the motivational sayings in each pair looked as follows: (Table 1)

Table 1: Points order of importance

\begin{tabular}{|l|l|l|}
\hline Option 1 & $\mathrm{A}=3$ points & $\mathrm{B}=0$ points \\
\hline Option 2 & $\mathrm{~A}=2$ points & $\mathrm{B}=1$ point \\
\hline Option 3 & $\mathrm{~A}=1$ point & $\mathrm{B}=2$ points \\
\hline Option 4 & $\mathrm{~A}=0$ points & $\mathrm{B}=3$ points \\
\hline
\end{tabular}

Source: own

In the questionnaire of personal career anchors, each respondent gradually counted an unclear formulation for each letter A, B, C, D, E, F, G, H, I, and recorded the totals for each code into the table of distribution of personal career anchors. The tables of distribution of personal career anchors serve to the respondents for the creation of personal ranking scales as motivational ones. The motivational scales were in Professional Counselling and Career Counselling applied as visualization aids for a formation of professional self-conception of the respondents. (Table 2) 
Table 2: Career anchors

\begin{tabular}{|l|}
\hline Distribution of personal career anchors \\
\hline A - Pay \\
\hline B - Power \\
\hline C - Meaning \\
\hline D - Expertise \\
\hline E - Creativity \\
\hline F - Solidarity \\
\hline G - Autonomy \\
\hline H - Security \\
\hline I - Status \\
\hline
\end{tabular}

Source: own

The questionnaire survey was conducted in the Silesian University in Opava, Faculty of Business Administration in Karviná (OPF SU) in winter and summer semesters of 2014/2015 in lessons of Professional Counselling with future bachelors and in lessons of Career Counselling with future engineers. Completing the questionnaire of personal career anchors was carried out as a research activity, and it took for each respondent 90 minutes. There were 450 questionnaires distributed and returned, therefore a response rate was 100\%. Empirical data, obtained from the questionnaire survey, were processed and evaluated by the cluster analysis, described by Řezanková, Húsek and Snášel (2009). The cluster analysis belongs to the group of multivariate statistical methods, which compile the research subjects into groups (clusters) on a base of similarity. The research objects of one cluster are by their properties more similar than research objects from other clusters. A basis of the cluster analysis is the input data matrix that contains monitored research objects and their variables. This is a similarity matrix that summarizes basic research objects, standing in the background of variability of characteristics of variables. The most common characteristics of relative variability is according the variation coefficient $\left(\mathrm{v}_{\mathrm{x}}\right)$, which is useful at comparing of variation of the variables. The variation coefficient is defined as a quotient of standard deviation and the arithmetic mean. If we want to assess what the variability of variables is (distribution of probability of a random quantity), we compare the standard deviation $\left(\mathrm{s}_{\mathrm{x}}\right)$ with the arithmetic mean $(\mathrm{x})$.

$$
v_{x}=\frac{s_{x}}{\bar{x}} \cdot 100[\%]
$$

The results of the cluster analysis are clusters of research objects with similar characteristics (variables), acquired by two-dimensional clustering, which at the same time cluster the research objects and variables. With reference to the objective - comparing the distribution of personal career anchors by the type of study program and the form of university study, a nonhierarchical clustering was used. Using the non-hierarchical clustering it is possible to get fixed/disjoint clusters, where each research object is placed in one cluster. In our case, the non-hierarchical cluster analysis reveals the distribution of personal career anchors as variables according to Schein concepts that are part of the fixed/disjoint clusters. For the evaluation of similarity of objects in clusters we use the degree of distance, where the mutual distances for all pairs of $\mathrm{n}$ objects are calculated. A distance matrix for quantitative variables is formed with an application of Euclidean metric, where "a" and "b" are vectors of the same number of elements.

$$
m_{e}(\vec{a}, \vec{b})=\sqrt{\sum_{i=1}^{n}\left(a_{i}-b_{i}\right)^{2}}
$$


The selection sets of respondents consisted of university students in developmental stages of early and middle adulthood. The early adulthood is a period of transition between adolescence and full adulthood. According to Langmeier and Krejčíŕová (2006, p. 167), the adulthood can by determined, taking into consideration the age, acceptation of development tasks and achieving a certain level of personal maturity. To developmental tasks of early adulthood by Langmeier and Krejčířová (2006, p. 168) belong mounting an adult identity, identification with the adult roles, productive orientation, clarification of personal goals, independence on parents, searching for a partner and creating a family. In the area of professional career it is a career decision and gradual obtaining accountability in the profession. In the developmental tasks there are involved a further consolidation, the peak of productivity and active searching for life goals, strengthening of responsibility in the adult role, responsibility for family and upbringing of children. In the area of the professional career it is a clear pursuit of objectives in occupation and independence on former mentors. Langmeier and Krejčířová (2006, p. 168) refer to the model of legitimate normative crisis, which assumes that the development in adulthood follows a sequence of social and emotional changes of an adult. In this context, there exists a general plan of human development that can be realized in different social conditions differently, but none of the developmental stages can be omitted.

The model of timing of life events assumes that a greater role in case of an adult are played by a variety of circumstances, indicated by significant life events. Langmeier and Krejčíŕová (2006, p. 169) point out that if there is a life event at a time when it is socially expected, the life events are referred to as normative and both the life path of an adult and the professional career are progressing smoothly. The respondents, who completed the questionnaire of personal career anchors, were not a general population of university students. By registering the optional advisory disciplines as learning subjects at SU OPF they expressed in the winter and summer semesters of the academic year 2014/2015 a committed interest in the topic of personal career anchors, which they found useful. By a quota purposive sampling, two selective samples were designed for the questionnaire survey. Based on defined subsets of the core set, we specifically chose the number of respondents for each sample individually. We had set a quota for selection of respondents from subgroups of students according to the registration for subjects Professional counselling - the future bachelors and Career counselling - future engineers. A prerequisite for application of the quota purposive selection method is according to Miovský (2009, p. 137) identifying and describing the criteria, by which the subgroups of a core set are distinguished, knowing how large the subgroups are and what their relative proportion is in terms of the sizr in the core set. The main differentiating factor in our case became the type of study program and the form of university education. (Table 3)

Table 3: Basic group of university students at OPF

\begin{tabular}{|c|c|c|c|c|c|}
\hline \multirow{2}{*}{\multicolumn{3}{|c|}{$\begin{array}{l}\text { Total } \\
\text { Type of study program }\end{array}$}} & 2045 & \multicolumn{2}{|c|}{$100,0 \%$} \\
\hline & & & \multicolumn{3}{|c|}{ Of study at university } \\
\hline \multirow[b]{2}{*}{ Bachelor's program } & \multirow[b]{2}{*}{1501} & \multirow[b]{2}{*}{$73,4 \%$} & Full-time students & 967 & $47,3 \%$ \\
\hline & & & Combined students & 534 & $26,1 \%$ \\
\hline \multirow[b]{2}{*}{ Master's program } & \multirow[b]{2}{*}{544} & \multirow[b]{2}{*}{$26,6 \%$} & Full-time students & 327 & $16,0 \%$ \\
\hline & & & Combined students & 217 & $10,6 \%$ \\
\hline
\end{tabular}

Source: SU OPF. IS STAG [online] [vid. $31^{\text {st }}$ August 2015]. Available from: stag.slu.cz/portal/studium/prohlizeni.html

According to fulfilled prerequisites, a set number of respondents was selected from subgroups of students and placed selection sets. A determination of quotas for selection of the number of respondents from subgroups of students was based on professional-qualification criteria (a 
study program at OPF and a form of university study). According to Miovský (2009, p. 138), during using an intentional quota selection it is important to define the variables the way that the different subgroups, of which we are selecting the set number of respondents, would be differentiated.

The intention was to create the selection sets, which shall provide a range of empirical data the cluster analysis of distribution of personal career anchors of OPF SU university students for the academic year 2014/2015. The first selection set consisted of students of the program, who registered for he subject Professional counselling. The second selection set consisted of students of the master's program of SU OPF, who registered for the subject Career Counselling. (Table 4)

Table 4: Selective groups of university students at OPF

\begin{tabular}{|c|c|c|c|c|c|c|}
\hline \multirow{2}{*}{\multicolumn{3}{|c|}{$\begin{array}{l}\text { Total } \\
\text { Type of study program }\end{array}$}} & 450 & \multicolumn{3}{|l|}{$100,0 \%$} \\
\hline & & & \multicolumn{4}{|c|}{ Of study at university } \\
\hline \multirow[b]{2}{*}{ Bachelor's program } & \multirow[b]{2}{*}{261} & \multirow[b]{2}{*}{$58,0 \%$} & Full & tudents & 198 & $44,0 \%$ \\
\hline & & & Com & students & 63 & $14,0 \%$ \\
\hline \multirow[b]{2}{*}{ Master's program } & \multirow[b]{2}{*}{189} & \multirow[b]{2}{*}{$42,0 \%$} & Full & tudents & 95 & $21,1 \%$ \\
\hline & & & Com & students & 94 & $20,9 \%$ \\
\hline
\end{tabular}

Source: own

\section{Results of cluster analysis}

The variation coefficients for distribution of order of personal career anchors according to the type of study program and a form of university study were summarized into four fixed/disjoint clusters. Four clusters (Table 5) show the distribution of personal career anchors of four subsets of university students of SU OPF Karviná for the academic year 2014/2015. After the application of the analysis, there were revealed the following similarities and differences in distribution of personal career anchors of the university students. We present some significant findings.

In the 1 anchor power/influence dominated. The second most important personal career anchor was the material reward. The least preferred personal career anchors was significance/meaning. The distribution of other personal career anchors in cluster 1 reflects a strong preference for security and autonomy. A moderate rate preference was attributed to sense of belonging. A low rate of preference was recorded in creativity, position and expertness.

In the 2 anchor significance/meaning dominated. The second most important was the personal career anchor power/influence. The least preferred personal career anchor has proven to be sense of belonging. A distribution of other personal career anchors in the 2 indicates the strong preference for creativity and autonomy. A moderate rate of preference was attributed to security and a low rate of was recorded in expertness and material reward.

In the 3 anchor autonomy dominated. The second most important was personal career anchor power/influence. Sense of belonging proved to be the least preferred. The distribution of other personal career anchors in the 3 indicates a strong preference of significance/meaning and creativity. A moderate rate preference was attributed to position and expertness. A low rate of preference was recorded in material reward and security.

In the 4 anchor of creativity dominated. The second most important was personal career anchor security. The least preferred proved to be significance/meaning. The distribution of 
other personal career anchors in the 4 indicates a strong preference of power/influence and autonomy. Moderate level of preference was shown sense of belonging and position. Low rate preference was experienced in expertness and material reward. (Table 5)

Table 5: Values of variables in hard/disjoint clusters

\begin{tabular}{|c|c|c|c|c|}
\hline Cluster 1 - Full-time students & $\mathrm{s}_{\mathrm{X}}$ & $\mathrm{x}$ & $\mathrm{v}_{\mathrm{x}}$ & Order \\
\hline A - Pay & 0,09 & 12,88 & 1,50 & 2. \\
\hline B - Power & 0,03 & 8,50 & 1,53 & 1. \\
\hline C - Meaning & 0,31 & 13,28 & 0,80 & 9. \\
\hline D - Expertise & 0,01 & 13,11 & 1,07 & 8. \\
\hline E - Creativity & 0,16 & 10,45 & 1,09 & 6,5 \\
\hline F - Solidarity & 0,20 & 12,64 & 1,16 & 5. \\
\hline G - Autonomy & 0,18 & 12,00 & 1,20 & 4. \\
\hline H - Security & 0,25 & 11,84 & 1,25 & 3. \\
\hline I - Status & 0,03 & 13,24 & 1,09 & 6,5 \\
\hline Cluster $2-$ Combined students & $\mathrm{s}_{\mathrm{x}}$ & $\mathrm{x}$ & $\mathrm{v}_{\mathrm{x}}$ & Order \\
\hline A - Pay & 0,04 & 12,13 & 0,87 & 8. \\
\hline B - Power & 0,05 & 8,31 & 1,25 & 2. \\
\hline C - Meaning & 0,22 & 13,92 & 1,30 & 1. \\
\hline D - Expertise & 0,18 & 14,45 & 0,98 & 7. \\
\hline E - Creativity & 0,36 & 9,99 & 1,24 & 3. \\
\hline F - Solidarity & 0,21 & 12,11 & 0,78 & 9. \\
\hline G - Autonomy & 0,03 & 12,04 & 1,08 & 4. \\
\hline H - Security & 0,03 & 12,05 & 1,02 & 5,5 \\
\hline I - Status & 0,66 & 12,90 & 1,02 & 5,5 \\
\hline Cluster 3 - Bachelors & $\mathrm{s}_{\mathrm{x}}$ & $\mathrm{x}$ & $\mathrm{v}_{\mathrm{x}}$ & Order \\
\hline A - Pay & 0,32 & 12,48 & 0,92 & 7. \\
\hline B - Power & 0,03 & 8,50 & 1,53 & 2. \\
\hline C - Meaning & 0,28 & 13,86 & 1,19 & 3. \\
\hline D - Expertise & 0,81 & 13,82 & 0,99 & 6. \\
\hline E - Creativity & 0,13 & 10,48 & 1,18 & 4. \\
\hline F - Solidarity & 0,27 & 12,17 & 0,80 & 9. \\
\hline G - Autonomy & 0,02 & 11,84 & 1,65 & 1. \\
\hline H - Security & 0,04 & 12,06 & 0,91 & 8. \\
\hline I - Status & 0,48 & 12,73 & 1,01 & 5. \\
\hline Cluster 4 - Engineers & $\mathrm{s}_{\mathrm{x}}$ & $\mathrm{x}$ & $\mathrm{v}_{\mathrm{x}}$ & Order \\
\hline A - Pay & 0,44 & 12,53 & 0,93 & 8. \\
\hline B - Power & 0,14 & 8,40 & 1,12 & 3. \\
\hline C - Meaning & 0,36 & 13,34 & 0,83 & 9. \\
\hline D - Expertise & 0,53 & 13,74 & 0,98 & 7. \\
\hline E - Creativity & 0,33 & 9,96 & 1,26 & 1. \\
\hline F - Solidarity & 0,27 & 12,58 & 1,03 & 5. \\
\hline G - Autonomy & 0,02 & 12,20 & 1,09 & 4. \\
\hline H - Security & 0,24 & 11,83 & 1,25 & 2. \\
\hline I - Status & 0,15 & 13,42 & 1,01 & 6. \\
\hline
\end{tabular}

Note: $s_{x}$ - standard deviation, $x$ - arithmetic mean, $v_{x}$ - coefficient of variation Source: own

\subsection{Discussion}

How will university students realize the impacts of Schein's concept of personal career anchors on clarifying of career expectations and formation of professional self-conception? The university students realize impacts of personal career anchors in different situations of career decision. Within professional decision they need to clarify the career expectations according 
to the current situation on the labour market and if the career expectations have the chance to be really fulfilled. University students form the professional self-conception in conformance with the motivational structure, comparison of interests, personal values and career preferences. Schein's studies from the 70s and 80s of the 20th century suggest that in the monitored US population is a distribution of career anchors as follows: $25 \%$ managerial competence, $25 \%$ technical and operational competence and 10\% autonomy. Remaining percents are spread among other career anchors. Schein (1996) mentions processes that occur between career anchors in changing economic environment. In terms of a career anchor, the security of organization moves away from guaranteeing a job security and offers a security of employability. For university students with a career anchor of security, it internally represents a need for a shift from a dependence on the employer towards a dependence on oneself. The said shift in an approach of organization is beneficial for university students with a career anchor of autonomy. The career anchors of security and autonomy are based on motives and needs. In case of security and autonomy it is important to align the job roles with basic personal desires and personal life. The differences between career anchors can be expected by the fundamental component, on which the university students are based. A university student can have only one real career anchor, which is substantially unchangeable. A change can be accepted only as a result of work experiences. If there are more dominant career anchors occurring among the university students, the cause of them is a lack of experience. University students with career anchors based on talent will have a higher degree of consensus between career anchors and work based on job performance and job stability. University students with career anchors based on needs will have the conformance mostly affected by managing of the job role and settling of the conflict of roles.

How will the university students find out, where they have the strongest personal career anchor? Attention in researches of experts was also paid to the self-employed workers, where the career anchors of autonomy and creativity dominate. According to these career anchors, the self-employed workers can be divided into two subgroups. The first subgroup, preferring autonomy, is encouraged by autonomy and independence more than by financial income and reached status. University students with career anchors of autonomy seek greater certainty in entrepreneurship, than is given to them by a job (Feldman, Bolino, 2000). With growing demand for new products and services, there are also growing opportunities for university students with career anchor of creativity. Creative university students are motivated to use their own skills and ideas for founding new organizations, where it is possible to earn money. In the contemporary world, there are favourable conditions for their mobility, because it allows an employment in such parts of the world, where one can find more favourable conditions for his/her own ideas. A space expands also for professional employment of university students with career anchor service, for whom it is important to perform meaningful work in a broader context. In combination with entrepreneurial creativity, the career anchor service leads to founding new organizations that deal with entrepreneurial plans. In connection with career anchors, there were found higher preferences in surveys in case of career anchor of autonomy, which distinguishes the university students aiming towards future business from the university students, advancing on the technical way (Trembley, Wils, Proulx, 2002).

The correlations between career anchors and personality types according to MBTI are documented by four bipolar career factors. The first is an interest in revival (career anchors of competition and managerial competence) in opposition to career anchors of security and service. The second is an interest in development of technical and functional competence in opposition to managerial competence. The third is an interest in autonomy against the career 
anchor of security. The fourth is a self-expression in case of career anchor of creativity, standing against career anchor of service (Nordvik, 1996). MBTI was also used by Maria Jarlstrom (2000) in research of relationships between career expectations and a personality. She compiled a research study on 533 Finnish students, where the career expectations were investigated by a question on notion of a future profession. According to the system of Schein's career anchors, there were identified three main career preferences of the Finnish students, which were matched by their career expectations (technical and functional competences - $26 \%$, managerial competence - $17 \%$, autonomy - 14\%). The preferences of career anchors and organizational cultures based on personality types were dealt by Warr and Pearce (2004), who had come to two groups of career anchors. The first type, marked "personal success" contains career anchors of technical and operational competence and managerial competence, autonomy, creativity and competition. The second type of "mutual security" contains career anchors of security, service and life balance. The strongest personality indicators for career preference of personal success were achieving objectives, monitoring, persuasion and vigour, while in case of mutual securing these were conventionality, caring, observing the rules and little inclination to a change. From the mentioned a preference for a career anchor and a type of organizational culture, which are aligned with the personality types of individuals, follows. What is the similarity and differences in preferences of personal career anchors of university students in the selection subsets according to the type of study program and a form of university study? According to the form of university study, the highest similarity in preference of order has the personal career anchor of autonomy, where identical objects (full-time and combined) have a distance measurement equal to 0 . Another cluster of similarity between the full-time and combined students is created by the personal career anchors power/influence, expertness and position. According to the type of program, three clusters of personal career anchors can be distinguished between objects (bachelors and engineers). The first cluster with the highest similarity is constituted by personal career anchors material reward, power/influence, expertise and position. (Table 6)

Table 6: Clusters with personal order of career anchors of students

\begin{tabular}{|l|l|l|l|l|}
\hline Career anchor & Cluster 1 & Cluster 4 & $\mathrm{m}_{\mathrm{e}}$ & Order \\
\hline A & 2. & 8. & 127,28 & 8. \\
\hline B & 1. & 2. & 21,21 & $2 .-4$. \\
\hline C & 9. & 1. & 169,71 & 9. \\
\hline D & 8. & 7. & 21,21 & $2 .-4$. \\
\hline E & $6,5$. & 3. & 74,25 & 6. \\
\hline F & 5. & 9. & 84,85 & 7. \\
\hline G & 4. & 4. & 0 & 1. \\
\hline H & 3. & $5,5$. & 53,03 & 5. \\
\hline I & $6,5$. & $5,5$. & 21,21 & $2 .-4$. \\
\hline Career anchor & Cluster 3 & Cluster 4 & $\mathrm{m}_{\mathrm{e}}$ & Order \\
\hline A & 7. & 8. & 21,21 & $1 .-4$. \\
\hline B & 2. & 3. & 21,21 & $1 .-4$. \\
\hline C & 3. & 9. & 127,28 & $8 .-9$. \\
\hline D & 6. & 7. & 21,21 & $1 .-4$. \\
\hline E & 4. & 1. & 63,64 & $5 .-6$. \\
\hline F & 9. & 5. & 84,85 & 7. \\
\hline G & 1. & 4. & 63,64 & $5 .-6$. \\
\hline H & 8. & 2. & 127,28 & $8 .-9$. \\
\hline I & 5. & 6. & 21,21 & $1 .-4$. \\
\hline
\end{tabular}

Note: $m_{e}$ - Euclidean metric

Source: own 
Other researches point to the possibility of more dominant career anchors of individuals (Ramakrishna and Potosky, 2003). There may exist the university students who have two significant career anchors, primary and secondary. The primary career anchor is based on talent and the secondary career anchor on needs and values of an individual. A reason for existence of two career anchors is the personal ambivalence, and ambivalence between two equally attractive targets (Feldman, Bolino, 1996). For that reason, it is recommended that the possibility of applying more career anchors will be taken into account mainly at the management of human resources in organizations. From the perspective of work of the HR managers it is desirable that HR managers choose a different approach towards university students with various career anchors. It is important to identify the career anchors and then to approach the university students according to them in an appropriate manner, which will help them to find meaning in work and to increase their work efficiency. The university students are aware that the senior management positions in a hierarchy of the organization are better rewarded, which motivates them towards promotion (Field, 2003).

\section{Conclusion}

The results of the questionnaire survey indicate the distribution of order related to personal career anchors of university students at SU OPF in the academic year 2014/2015. The conclusions of the questionnaire survey, however, need to be interpreted with caution. It is only possible to generalize the conclusions about distribution of order of personal career anchors to the university students of SU OPF, not to the university students as a target group. For these reasons, the conclusions are formulated in general terms and only for the university students from selection subsets. On the other hand, the results that we have reached are in the concept of personal Schein's career anchors understandable. With every personal career anchor that the university students realize, the clarification of their career expectations and formation of professional selfconception becomes more effective. Knowledge of career anchors is beneficial, particularly among middle managers, who head towards a further development of the personal professional career. An improved self-esteem and a self-knowledge allow them to influence the personal professional career more actively. A problem is the application of career anchors between young managers with a lack of work experiences that are necessary for forming of the career anchors (Evans, 1996). The professional self-conception will be formed by students at SU OPF more efficiently according to the personal motivational structure, interests, personal values and career preferences. If they manage to clarify the career expectations by Schein's concept of personal career anchors, the career expectations have more realistic chance to be really fulfilled. However, the fact remains, that the situation of career decisions is more considered a professional opportunity by combining students than full-time students. In this context it is important that a certain type of personal career anchor is for the student a feature, characterised by personality, i.e. more or less dominant and relatively constant. The distribution of order of the personal career anchors therefore contributes to understanding of the job profiles of university students of SU OPF, which characterizes the students' motivation to work (Nordvik, 1996). The working profiles therefore represent a synthetic, individually specific and throughout university studies stable characteristic of university students. In a professional career, they will play vital tasks that must be fulfilled. When they look at life tasks, they take into consideration the different areas of the career as a way of life. For these reasons, it is advisable to create the target photographs individually and specifically.

\section{Acknowledgement}

This article was created under support of the Ministry of Education, Youth and Sports under the Institutional Support for long-term strategic development of the Silesian University in Opava, Faculty of Business Administration in Karviná in year 2016. 


\section{References}

[1] BĚLOHLÁVEK, F., 1994. Osobni kariéra. Praha: Grada Publishing. ISBN 80-7169063-X.

[2] EVANS, C., 1996. A review of career anchors in use. European Journal of Work and Organizational Psychology, 5(4), 609-615. ISSN 1359-432X.

[3] FELDMAN, D. C. and M. C. BOLINO, 1996. Careers within careers: Reconceptualizing the nature of career anchors and their consequences. Human Resource Management Review, 6(2), 89-112. ISSN 1053-4822.

[4] FELDMAN, D. C. and M. C. BOLINO, 2000. Career patterns of the self-employed: Career motivations and career outcomes. Journal of Small Business Management, 38(3), 53-67. ISSN 0047-2778.

[5] FIELD, A., 2003. Speak to what drives them. Identifying the motivations that anchor employes' careers can help managers spur and reward achievement in a high-demand economy. Harvard Management Communication Letter, 6(9), 3-5. ISSN 1524-5519.

[6] HARDIN, R. J., M. H. STOCKS and O. F. GRAVES, 2001. The effect of match or mismacht between the career anchors and the job settings of CPAs: An empirical analysis. Advances in Accounting, 18(6), 119-148. ISSN 0-7623-0719-6.

[7] JARLSTROM, M., 2000. Personality preferences and career expectations of Finish business students. Career Development International, 5(3), 144-154. ISSN 1362-0436.

[8] LANGMEIER, J. a D. KREJČÍŘOVÁ, 2006. Vývojová psychologie. 2. vyd. Praha: Grada Publishing. ISBN 80-247-1284-9.

[9] LEE, S. H. and P. K. WONG, 2004. An exploratory study of technopreneurial Intentions: A career anchor perspektive. Journal of Business Venturing, 19(1), 7-28. ISSN 08839026.

[10] LEMROVÁ, S. a Z. VTÍPIL, 2005. Scheinův systém kariérových kotev a jeho využití. Acta Universitatis Palackianae Olomucensis, 34(1), 89-104. ISSN 1214-3254.

[11] MIOVSKÝ, M., 2009. Kvalitativní přistup a metody v psychologickém výzkumu. Praha: Grada Publishing. ISBN 80-247-1362-4.

[12] NORDVIK, H., 1996. Relationships between Holland's vocational typology, Schein's career anchor and Myers-Briggs' types. Journal of Occupational \& Organizational Psychology, 69(3), 263-275. ISSN 0963-1798.

[13] RAMAKRISHNA, H. and D. POTOSKY, 2003. Conceptualization and exploration of composite career anchors: An analysis of information systems personnel. Human Resource Development Quarterly, 14(2), 199-214. ISSN 1044-8004.

[14] REICHEL, J., 2009. Kapitoly metodologie sociálnich výzkumů. Praha: Grada Publishing. ISBN 978-80-247-3006-6.

[15] ŘEZANKOVÁ, H., D. HÚSEK a V. SNÁŠEL, 2009. Shluková analýza dat. 2. vyd. Praha: Professional Publishing. ISBN 978-80-86946-81-8.

[16] SCHEIN, E. H., 1978. Career dynamics. Matching individual and organizational needs. Addison-Wesley: Reading. ISBN 0201068346.

[17] SCHEIN, E. H., 1990. Career anchors: Discovering your real values. San Diego CA: Pfeifer\&Company. ISBN 0-88390-030-0. 
[18] SCHEIN, E. H., 1994. Commentary: What is an entrepreneur? Entrepreneurship Theory and Practice, 19, 87-88. ISSN 1042-2587.

[19] SU OPF. IS STAG [online]. [vid. 31 ${ }^{\text {st }}$ August 2015]. Available from: stag.slu.cz/portal/studium/prohlizeni.html

[20] SU OPF, 2015. Study in Karviná. Information concerning the study for the academy year 2015/2016 [online]. [cit. $5^{\text {th }}$ November 2015]. Available from: studujvkarvine.cz/opf.slu.cz/

[21] TREMBLAY, M., T. WILS and C. PROULX, 2002. Determinants of career path preferences among Canadian engineers. Journal of Engineering and Technology Management, 19(1), 1-23. ISSN 0923-4748.

[22] WARR, P. and A. PEARCE, 2004. Preferences for careers and organizational culture as a function of logically related personality trains. Applied Psychology An International Review, 53, 423-435. ISSN 0269-994X. 